\title{
Effect of beta1- and beta2-adrenergic stimulation on energy expenditure, substrate oxidation, and UCP3 expression in humans
}

Citation for published version (APA):

Hoeks, J., van Baak, M. A., Hesselink, M. K. C., Hul, G. B. J., Vidal, H., Saris, W. H. M., \& Schrauwen, P. (2003). Effect of beta1- and beta2-adrenergic stimulation on energy expenditure, substrate oxidation, and UCP3 expression in humans. American Journal of Physiology : Endocrinology and Metabolism, 285(4), E775-E782. https://doi.org/10.1152/ajpendo.00175.2003

Document status and date:

Published: 01/01/2003

DOI:

10.1152/ajpendo.00175.2003

Document Version:

Publisher's PDF, also known as Version of record

Please check the document version of this publication:

- A submitted manuscript is the version of the article upon submission and before peer-review. There can be important differences between the submitted version and the official published version of record.

People interested in the research are advised to contact the author for the final version of the publication, or visit the DOI to the publisher's website.

- The final author version and the galley proof are versions of the publication after peer review.

- The final published version features the final layout of the paper including the volume, issue and page numbers.

Link to publication

\footnotetext{
General rights rights.

- You may freely distribute the URL identifying the publication in the public portal. please follow below link for the End User Agreement:

www.umlib.nl/taverne-license

Take down policy

If you believe that this document breaches copyright please contact us at:

repository@maastrichtuniversity.nl

providing details and we will investigate your claim.
}

Copyright and moral rights for the publications made accessible in the public portal are retained by the authors and/or other copyright owners and it is a condition of accessing publications that users recognise and abide by the legal requirements associated with these

- Users may download and print one copy of any publication from the public portal for the purpose of private study or research.

- You may not further distribute the material or use it for any profit-making activity or commercial gain

If the publication is distributed under the terms of Article $25 \mathrm{fa}$ of the Dutch Copyright Act, indicated by the "Taverne" license above, 


\title{
Effect of $\beta_{1^{-}}$and $\beta_{2}$-adrenergic stimulation on energy expenditure, substrate oxidation, and UCP3 expression in humans
}

\author{
Joris Hoeks, ${ }^{1}$ Marleen A. van Baak, ${ }^{1}$ Matthijs K. C. Hesselink, ${ }^{2}$ Gabby B. Hul, ${ }^{1}$ \\ Hubert Vidal, ${ }^{3}$ Wim H. M. Saris, ${ }^{1}$ and Patrick Schrauwen ${ }^{1}$ \\ Departments of ${ }^{1}$ Human Biology and ${ }^{2}$ Movement Sciences, Nutrition and Toxicology Research Institute \\ Maastricht, Maastricht University, 6200 MD Maastricht, The Netherlands; and ${ }^{3}$ Institut National de la \\ Santé et de la Recherche Médicale Unit 449, Faculty of Medicine RTH Laennec, 69372 Lyon, France
}

Submitted 16 April 2003; accepted in final form 19 June 2003

\begin{abstract}
Hoeks, Joris, Marleen A. van Baak, Matthijs K. C. Hesselink, Gabby B. Hul, Hubert Vidal, Wim H. M. Saris, and Patrick Schrauwen. Effect of $\beta_{1}$ - and $\beta_{2}$-adrenergic stimulation on energy expenditure, substrate oxidation, and UCP3 expression in humans. Am J Physiol Endocrinol Metab 285: E775-E782, 2003. First published June 24, 2003; 10.1152/ajpendo.00175.2003.-In humans, $\beta$-adrenergic stimulation increases energy and fat metabolism. In the case of $\beta_{1}$-adrenergic stimulation, it is fueled by an increased lipolysis. We examined the effect of $\beta_{2}$-adrenergic stimulation, with and without a blocker of lipolysis, on thermogenesis and substrate oxidation. Furthermore, the effect of $\beta_{1}$ and $\beta_{2}$-adrenergic stimulation on uncoupling protein 3 (UCP3) mRNA expression was studied. Nine lean males received a 3 -h infusion of dobutamine $\left(\mathrm{DOB}, \beta_{1}\right)$ or salbutamol (SAL, $\beta_{2}$ ). Also, we combined SAL with acipimox to block lipolysis (SAL + ACI). Energy and substrate metabolism were measured continuously, blood was sampled every $30 \mathrm{~min}$, and muscle biopsies were taken before and after infusion. Energy expenditure significantly increased $\sim 13 \%$ in all conditions. Fat oxidation increased $47 \pm 7 \%$ in the DOB group and $19 \pm 7 \%$ in the SAL group but remained unchanged in the SAL+ACI condition. Glucose oxidation decreased $40 \pm$ 9\% upon DOB, remained unchanged during SAL, and increased $27 \pm 11 \%$ upon SAL + ACI. Plasma free fatty acid (FFA) levels were increased by SAL $(57 \pm 11 \%)$ and DOB $(47 \pm 16 \%)$, whereas SAL +ACI caused about fourfold lower FFA levels compared with basal levels. No change in UCP3 was found after DOB or SAL, whereas SAL+ACI downregulated skeletal muscle UCP3 mRNA levels $38 \pm 13 \%$. In conclusion, $\beta_{2}$-adrenergic stimulation directly increased energy expenditure independently of plasma FFA levels. Furthermore, this is the first study to demonstrate a downregulation of skeletal muscle UCP3 mRNA expression after the lowering of plasma FFA concentrations in humans, despite an increase in energy expenditure upon $\beta_{2}$-adrenergic stimulation.
\end{abstract}

uncoupling protein 3; thermogenesis; adrenergic receptors; sympathetic nervous system

IN RODENTS, THE MAJOR SITE of thermogenesis is the brown adipose tissue (BAT), and a key molecule in BAT thermogenesis is uncoupling protein 1 (UCP1). This protein dissipates the mitochondrial proton gradient

Address for reprint requests and other correspondence: J. Hoeks, NUTRIM, Dept. of Human Biology, Maastricht Univ., PO Box 616 6200 MD Maastricht, The Netherlands (E-mail: j.hoeks@hb. unimaas.nl).

http://www.ajpendo.org

0193-1849/03 \$5.00 Copyright @ 2003 the American Physiological Society

The costs of publication of this article were defrayed in part by the payment of page charges. The article must therefore be hereby marked "advertisement" in accordance with 18 U.S.C. Section 1734 marked "advertisement" in

by catalyzing the backflow of protons into the mitochondrial matrix, thereby generating heat (8). Sympathetic stimulation increases energy expenditure in rodents by several methods, one of which is by stimulating BAT thermogenesis (9). BAT contains all three $\beta$-adrenergic receptor subtypes, each of which is coupled to a $\mathrm{G}$ protein to stimulate adenylate cyclase and, thereby, the cAMP/PKA pathway (2).

In humans, both $\beta_{1}$-adrenergic stimulation and $\beta_{2^{-}}$ adrenergic stimulation also increase energy expenditure $(19,20)$. However, in contrast to rodents, $\beta$-adrenergic-stimulated thermogenesis in humans is mainly located in skeletal muscle $(25,26)$, and the mechanism is still unknown. Besides increasing energy expenditure, both $\beta_{1}$ - and $\beta_{2}$-adrenergic stimulations also increase adipose tissue lipolysis $(19,20)$, and it has been shown that the increased lipolysis is responsible for a great part of the increase in energy expenditure after $\beta_{1}$-adrenergic stimulation (18). However, since $\beta_{2}$-adrenergic receptors are mainly localized in skeletal muscle and not in adipocytes, it can be hypothesized that $\beta_{2}$-adrenergic stimulation may exert a direct effect on energy expenditure. Therefore, the first aim of the present study was to examine the effect of $\beta_{2}$-adrenergic stimulation, with and without a blocker of lipolysis, on energy and substrate metabolism.

As mentioned above, the mechanism through which sympathetic stimulation might increase energy expenditure in skeletal muscle is still unknown. UCP3, which shows $\sim 55 \%$ amino acid homology with UCP1 and is predominantly expressed in skeletal muscle (1, 28), has been reported to have uncoupling activity (5, 7). With respect to the possible role of UCP3 in human thermogenesis, we reported that UCP3 mRNA expression was positively correlated with sleeping metabolic rate in Pima Indians, suggesting that skeletal muscle UCP3 is a mediator in the regulation of energy metabolism (24). More recently, however, we reported that human UCP3 probably plays a role in fatty acid metabolism, with uncoupling as a possible secondary effect $(22,23)$. Therefore, UCP3 could either directly or indirectly be involved in $\beta$-adrenergic receptor-stimu- 
lated thermogenesis. In this respect, animal and cell culture studies have revealed controversial data regarding the effect of $\beta$-adrenergic stimulation on UCP3 expression. Nakamura et al. (14) reported that skeletal muscle UCP3 in mice was upregulated after treatment with a $\beta_{3}$-adrenergic agonist. However, free fatty acid levels were also increased after $\beta_{3}$-adrenergic stimulation, which could have caused the observed effect on UCP3 expression (29). In addition, Gomez-Abrosi et al. (6) were unable to detect any changes in skeletal muscle UCP3 expression upon short-term $\beta_{3}$-adrenergic stimulation in male Wistar rats. However, Nagase et al. (13) showed that stimulation of L6 myotubes with epinephrine increased UCP3 mRNA levels and that the regulatory effects of catecholamines were mediated through the $\beta_{2}$-adrenergic receptor pathway. Regardless of the controversial data in animal studies and cell culture systems, no data are currently available on the effect of $\beta$-adrenergic activity on UCP3 mRNA expression in human skeletal muscle.

Therefore, the second aim of the present study was to examine the effect of $\beta$-adrenergic stimulation $\left(\beta_{1}\right.$ or $\beta_{2}$ ) in healthy lean human subjects on the expression of skeletal muscle UCP3 mRNA. Because high fatty acid levels are known to upregulate $\operatorname{UCP} 3(11,17,29)$, we examined the effect of $\beta_{2}$-adrenergic stimulation on UCP3 mRNA expression independent of the effect of increased lipolysis.

\section{MATERIALS AND METHODS}

Subjects. Nine healthy lean male volunteers participated in this study. Subject characteristics are displayed in Table 1. All subjects were in good health as assessed by medical history and physical examination. All subjects engaged in sports activities $\leq 2 \mathrm{~h} / \mathrm{wk}$, and none had physically demanding jobs.

The study protocol was reviewed and approved by the Medical Ethics Committee of Maastricht University, and all subjects gave written informed consent before participating in the study.

Experimental design. Subjects arrived at the laboratory at 8:00 AM after an overnight fast. Subjects were asked to avoid physical activity before the test. All subjects performed tests under three different conditions in a randomized crossover design. Between conditions, a washout period of $\geq 1$ wk was maintained.

On the subject's arrival at the laboratory, a percutaneous muscle biopsy was taken from the vastus lateralis muscle. After local anesthesia ( $0.2 \%$ xylocaine without epinephrine), a 5-mm-diameter side-cutting needle was passed through a 7-mm skin incision. The muscle biopsy was frozen immediately in liquid nitrogen and stored at $-80^{\circ} \mathrm{C}$ until assayed. Subsequently, two Teflon cannulas were inserted into an

\section{Table 1. Subject characteristics}

\begin{tabular}{ll}
\hline \hline & Means $\pm \mathrm{SE}$ \\
\hline Body weight, $\mathrm{kg}$ & $71.5 \pm 3.2$ \\
Fat-free mass, $\mathrm{kg}$ & $58.0 \pm 2.7$ \\
Height, $\mathrm{m}$ & $1.79 \pm 0.03$ \\
Body mass index, $\mathrm{kg} / \mathrm{m}^{2}$ & $22.2 \pm 0.8$ \\
Age, yr & $24.4 \pm 1.3$ \\
\hline
\end{tabular}

antecubital vein of each arm. One cannula was used for the infusion of $\beta$-adrenergic agonists and one cannula for sampling of blood. After the muscle biopsy was taken and cannulas were placed, subjects rested on a bed for $\sim 2 \mathrm{~h}$ to avoid induction of endogenous stress hormone levels. Next, oxygen consumption and carbon dioxide production were measured for 30 min by use of a custom-made ventilated hood system (Omnical, Maastricht University, The Netherlands). After 30 min, a first blood sample was taken (time 0). After this, a continuous infusion of either $4.6 \mu \mathrm{g} \cdot \mathrm{kg}_{\mathrm{FFM}}{ }^{-1} \cdot \mathrm{min}^{-1}$ dobutamine (DOB, a selective $\beta_{1}$-adrenergic receptor agonist; Dobax, Zwanenburg, The Netherlands) or $77 \mathrm{ng} \cdot \mathrm{kg}_{\mathrm{FFM}}{ }^{-1}$. $\min ^{-1}$ salbutamol (SAL, a selective $\beta_{2}$-adrenergic receptor agonist; Ventolin, GlaxoSmithKline, Zeist, The Netherlands) was started and maintained for $3 \mathrm{~h}$. The third condition (SAL + ACI) consisted of salbutamol infusion combined with simultaneous blocking of lipolysis by acipimox. To that purpose, two doses of 250-mg acipimox were given orally at -120 min and time 0 . Blood samples were taken every $30 \mathrm{~min}$, and ventilated hood measurements were continued throughout the experiment. After the $3 \mathrm{~h}$ of infusion, a second muscle biopsy was taken.

Body composition. One week before the first test, body density was determined by hydrostatic weighing in the morning in the fasted state. Body weight was measured with a digital balance with an accuracy of $0.01 \mathrm{~kg}$ (Sauter, type E1200). Lung volume was measured simultaneously with the helium dilution technique by a spirometer (Volugraph 2000, Mijnhardt). Body composition was calculated according to the equation of Siri (27). Fat-free mass was calculated by subtracting fat mass from total body weight.

Indirect calorimetry. Whole body energy expenditure and substrate oxidation were measured by indirect calorimetry by use of a custom-made ventilated hood system (Omnical, Maastricht University, The Netherlands). The volume of air drawn through the hood was measured by a dry gas meter (Schlumberger, Dordrecht, The Netherlands), and the composition of the in- and outflowing air was analyzed by a paramagnetic $\mathrm{O}_{2}$ analyzer (Servomex, Crowborough, UK) and an infrared $\mathrm{CO}_{2}$ analyzer (Hartmann en Braun, Frankfurt, Germany). The airflow rate and the $\mathrm{O}_{2}$ and $\mathrm{CO}_{2}$ concentrations were used to compute $\mathrm{O}_{2}$ consumption and $\mathrm{CO}_{2}$ production on-line through an automatic acquisition system connected to a personal computer. $\mathrm{O}_{2}$ consumption and $\mathrm{CO}_{2}$ production were averaged over the last $15 \mathrm{~min}$ of each $30-\mathrm{min}$ time interval. Energy expenditure was calculated according to the Weir formula (30). Total carbohydrate and fat oxidation values were calculated using stoichiometric equations (16).

Blood analysis. Blood for determination of plasma free fatty acids (FFA) was collected in tubes containing $30 \mu \mathrm{l}$ of 0.2 M EDTA. Blood was immediately centrifuged at high speed, and plasma was transferred to Eppendorf tubes. Plasma was rapidly frozen in liquid nitrogen and stored at $-20^{\circ} \mathrm{C}$ until further analysis. Plasma FFA concentrations were measured using the Wako NEFA C kit (Wako Chemicals, Neuss, Germany).

Quantitation of UCP3 $m R N A$. Total RNA was extracted from skeletal muscle biopsies using TRIzol reagent (Invitrogen, Breda, The Netherlands). First-strand cDNAs were first synthesized from $1 \mu \mathrm{g}$ of total RNA in the presence of 100 units of Superscript II (Invitrogen, Eragny, France) with use of both random hexamers and oligo(dT) primers (Promega, Charbonnières, France). Real-time PCR was performed using a LightCycler (Roche Diagnostics, Meylan, France) in a final volume of $20 \mu \mathrm{l}$ containing $5 \mu \mathrm{l}$ of a 100 -fold dilution of the 
reverse transcription reaction and $15 \mu \mathrm{l}$ of reaction buffer from the FastStart DNA Master SYBR Green kit (Roche Diagnostics) with $3 \mathrm{mM}$ of $\mathrm{MgCl}_{2}$ and the specific forward (5'-ATGGACGCCTACAGAACCAT-3') and reverse (5'-CTGGGCCACCATCTTTATCA-3') UCP3 primers (Sigma-Genosys, Cambridgeshire, UK). After amplification, a melting curve analysis was performed to verify the specificity of the reaction. For quantification, a standard curve was systematically generated with six different amounts (150 to 30,000 molecules/tube) of human UCP3 cDNA cloned in the pGEM plasmid (Promega). To correct for possible variations in the efficiency of the reverse transcription, a reference gene (cyclophilin) was simultaneously measured using the specific forward (5'-GCCATGGAGCGCTTTGG-3') and reverse (5'CCACAGTCACGAATGGTGATC-3') cyclophilin primers. The levels of UCP3 mRNA were normalized to cyclophilin mRNA expression and used as a housekeeping marker, and values were expressed as the ratio of UCP3 and cyclophilin. The analysis was performed using the LightCycler software (Roche Diagnostics).

Statistical analysis. All values are expressed as means \pm SE. Changes in energy expenditure, plasma FFAs, fat oxidation, and glucose oxidation were calculated as total area under the curve (AUC) minus baseline values. Differences between conditions were evaluated by analysis of variance (one-way ANOVA). When significant differences were found, a Bonferroni adjusted post hoc test was used to determine the exact location of the difference. Pre- and postexperimental differences within groups were analyzed pairwise by Student's $t$-tests. Outcomes were regarded as statistically significant if $P<0.05$.

\section{RESULTS}

Energy expenditure and substrate oxidation. Baseline energy expenditure was similar in all three conditions $[5.51 \pm 0.30,5.24 \pm 0.35$, and $4.97 \pm 0.28 \mathrm{~kJ} / \mathrm{min}$ in DOB, SAL, and SAL+ACI, respectively, not signifi- cant (NS)]. Upon $\beta$-adrenergic stimulation, energy expenditure increased and remained stable during the entire 3-h infusion period (Fig. 1). Dobutamine (DOB) infusion resulted in a $0.58 \pm 0.20 \mathrm{~kJ} / \mathrm{min}(P<0.05)$ increase in energy expenditure, whereas the SAL and SAL + ACI conditions showed a $0.72 \pm 0.12(P<0.001)$ and $0.62 \pm 0.12(P<0.001) \mathrm{kJ} / \mathrm{min}$ increase, respectively. No significant difference existed among conditions regarding the increase in energy expenditure (Fig. 2).

Figure 3 displays the changes in respiratory exchange ratio (RER) during the $\beta$-adrenergic stimulation. From this ratio, fat and glucose oxidation were calculated. At baseline, fat oxidation was similar between conditions $(81.5 \pm 5.7,75.5 \pm 10.8$, and $63.7 \pm$ $9.2 \mathrm{mg} / \mathrm{min}$ in DOB, SAL, and SAL+ACI respectively, NS). Administration of dobutamine or salbutamol significantly increased the oxidation of fatty acids by $38.0 \pm 5.9$ and $14.3 \pm 5.5 \mathrm{mg} / \mathrm{min}$, respectively $(P<$ $0.05)$. The increase in fat oxidation after salbutamol administration was completely absent when acipimox was coadministered $(-1.0 \pm 6.8 \mathrm{mg} / \mathrm{min}$; NS $)$. The increase in fat oxidation (Fig. 4A) was significantly higher in the DOB condition than in either SAL or SAL + ACI condition $(P<0.005)$.

Glucose oxidation did not show statistically significant differences between conditions at baseline $(147.9 \pm 12.7,146.2 \pm 23.7$, and $158.5 \pm 13.9 \mathrm{mg} / \mathrm{min}$ in DOB, SAL, and SAL+ACI, respectively, NS). Glucose oxidation (Fig. $4 B$ ) significantly decreased by $58.5 \pm 13.4 \mathrm{mg} / \mathrm{min}(P<0.005)$ upon dobutamine administration, whereas no change was detected during salbutamol infusion (+10.3 $\pm 11.8 \mathrm{mg} / \mathrm{min}, \mathrm{NS})$. However, addition of acipimox to salbutamol signifi-

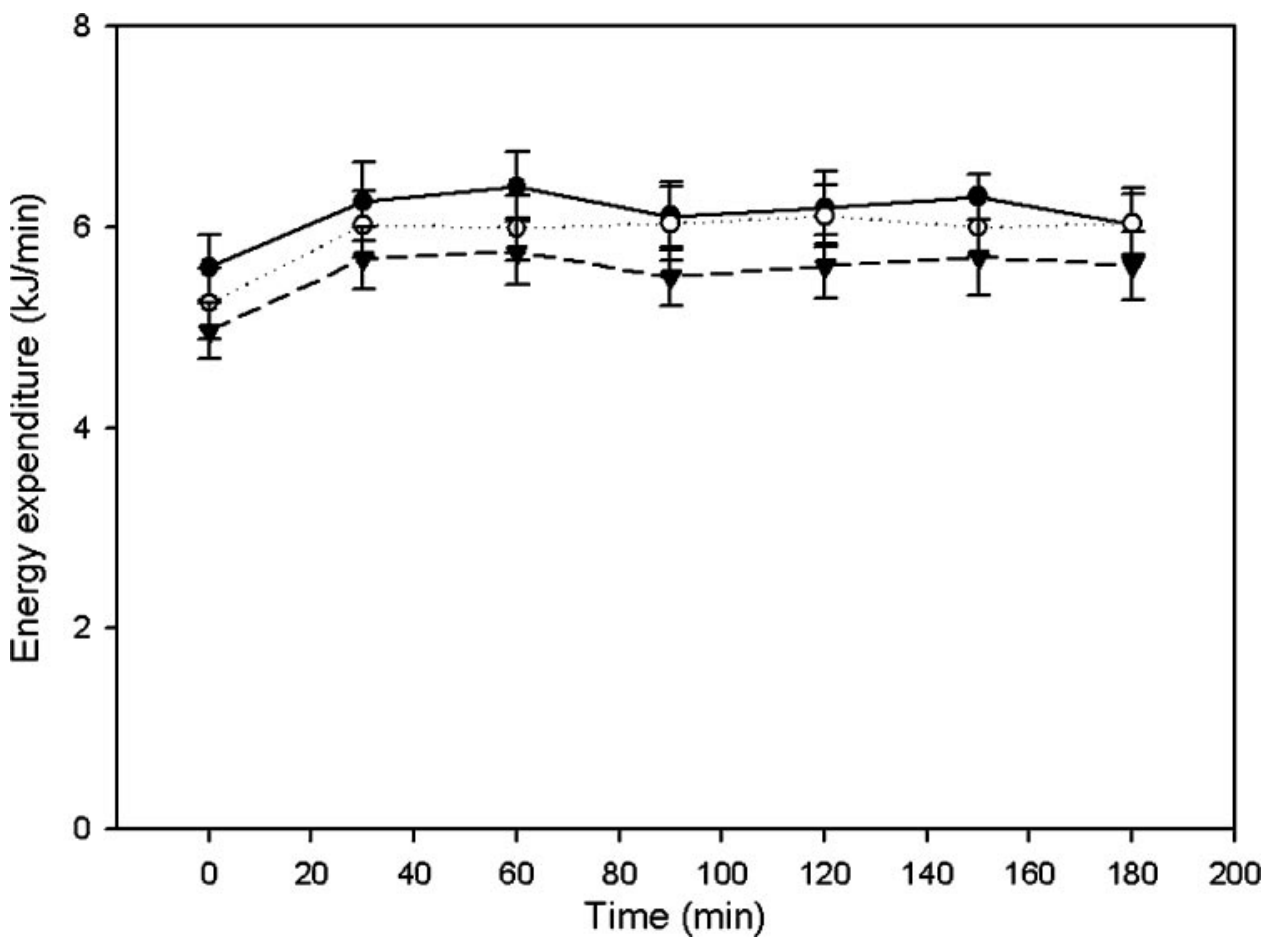

Fig. 1. Energy expenditure during $\beta$-adrenergic stimulation. Values are means \pm SE. $\bullet$, dobutamine (DOB); $\circ$, salbutamol (SAL); $\mathbf{\nabla}, \mathrm{SAL}+$ acipimox (ACI). 


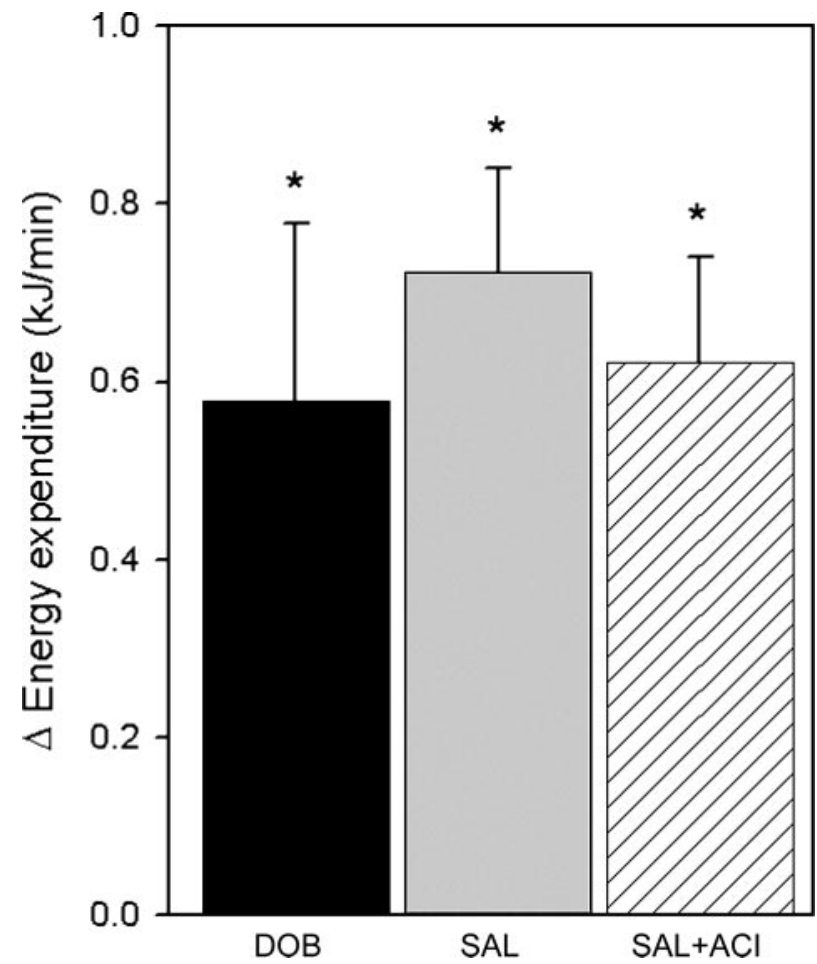

Fig. 2. Changes in energy expenditure upon $\beta$-adrenergic stimulation. Values (means $\pm \mathrm{SE}$ ) are areas under the curve (AUC) of energy expenditure vs. time minus baseline $(\mathrm{kJ} / \mathrm{min})$. Solid bar, DOB; gray bar, SAL; hatched bar, SAL+ACI. ${ }^{*} P<0.05$ vs. baseline.

cantly increased glucose oxidation by $42.5 \pm 17.5 \mathrm{mg} /$ $\min (P<0.05)$.

Blood and muscle substrates. Baseline plasma FFA concentrations were significantly lower after administration of acipimox than after either the DOB or SAL condition $(67.0 \pm 13.3$ vs. $443.7 \pm 72.2$ and $341.3 \pm$ $68.1 \mu \mathrm{mol} / \mathrm{l}$ in SAL+ACI vs. DOB and SAL, respectively, $P<0.001$ ). Upon $\beta$-adrenergic stimulation, FFA levels significantly rose in all conditions $(209 \pm 72$,
$196 \pm 37$, and $57 \pm 19 \mu \mathrm{mol} / \mathrm{l}$ in $\mathrm{DOB}$, SAL, and SAL +ACI, respectively, $P<0.05$ ), although the increase in plasma FFA in the SAL+ACI condition was approximately fourfold lower than during either dobutamine or salbutamol infusion (Fig. 5).

Basal UCP3 mRNA levels were not significantly different among the three conditions (DOB: $43 \pm 12$; SAL: $52 \pm 14$; SAL+ACI: $79 \pm 12$ arbitrary units, NS). Simultaneous administration of salbutamol and acipimox significantly lowered UCP3 mRNA levels $38 \pm$ $13 \%(P<0.05)$. However, neither dobutamine nor salbutamol administration alone altered UCP3 expression significantly (Fig. 6).

\section{DISCUSSION}

In rodents, UCP1, located in the inner mitochondrial membranes of BAT, plays an important role in sympathetic stimulation-induced adaptive thermogenesis (10). In contrast, in humans, skeletal muscle is responsible for a major part of $\beta$-adrenergic-induced thermogenesis $(25,26)$. UCP3, primarily localized in skeletal muscle $(1,28)$, is a candidate for explaining sympathetic stimulation-induced adaptive thermogenesis, but possible regulation of UCP3 expression by the sympathetic nervous system has not yet been studied in humans. Here, we show that $\beta_{1^{-}}$or $\beta_{2}$-adrenergic receptor stimulation is not involved in the regulation of UCP3 mRNA expression.

In the present study, energy expenditure significantly increased upon both $\beta_{1^{-}}$(dobutamine) and $\beta_{2^{-}}$ adrenergic stimulation (salbutamol). It was previously shown that the increase in energy expenditure upon $\beta_{1}$-adrenergic stimulation was an indirect effect, fueled by plasma FFAs released from adipose tissue (18). However, in contrast to $\beta_{1}$-adrenergic receptors, $\beta_{2^{-}}$ adrenergic receptors are primarily located in skeletal muscle; therefore, we hypothesized that the $\beta_{2}$-adrenergic-induced increase in energy expenditure would be
Fig. 3. Respiratory exchange ratio during $\beta$-adrenergic stimulation. Values are means $\pm \mathrm{SE}$. $\bullet$ DOB; o, SAL; $\mathbf{v}$, SAL + ACI.

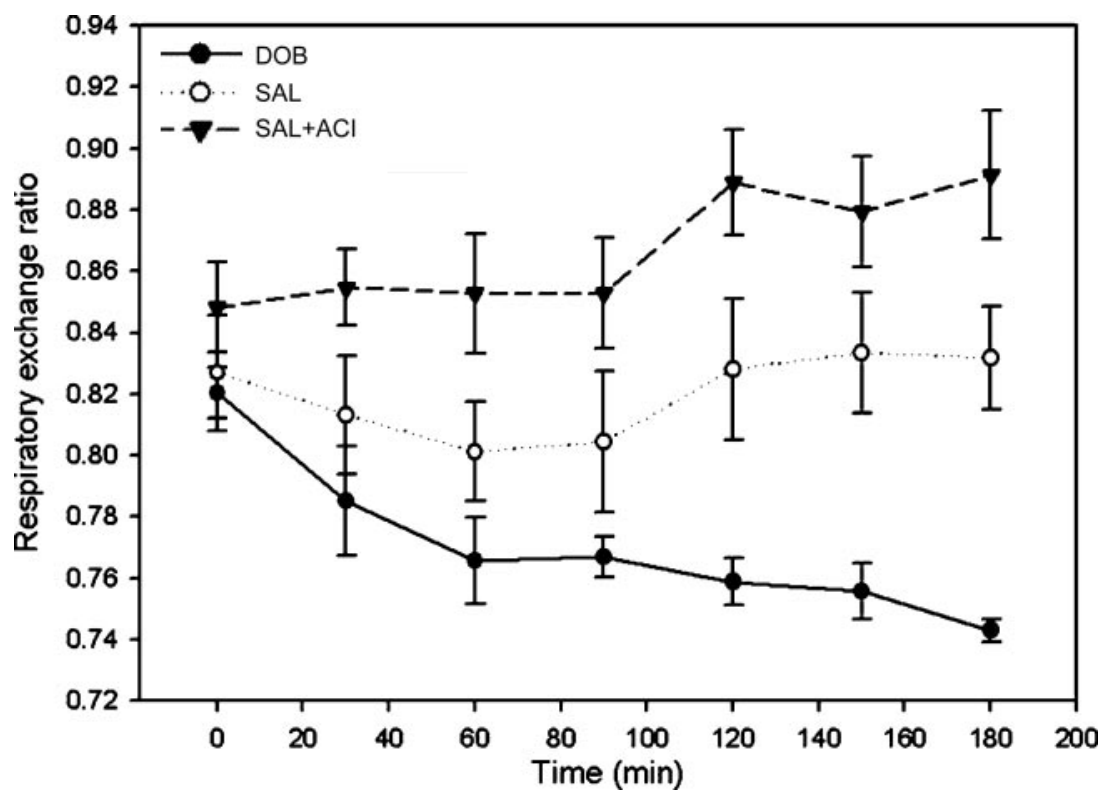



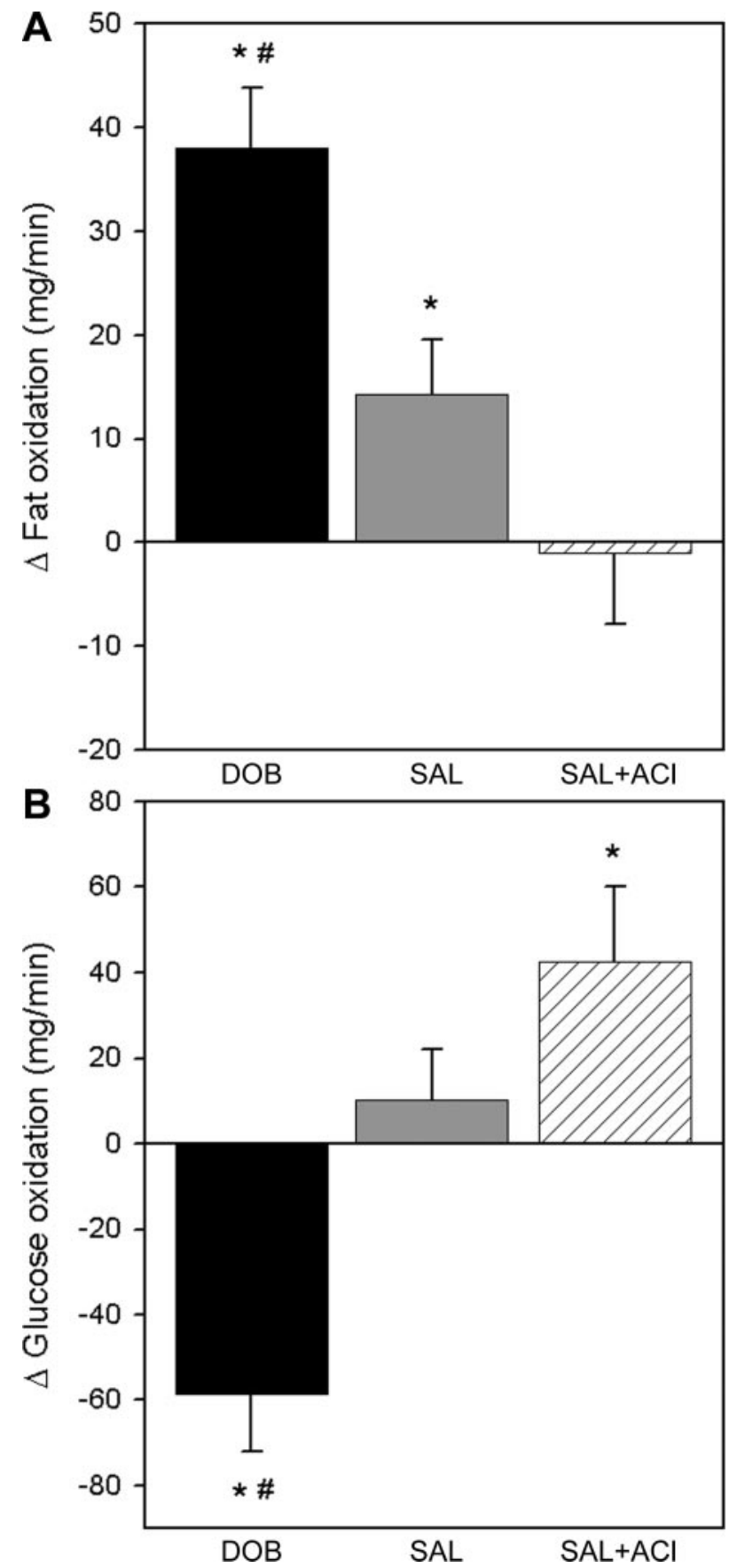

Fig. 4. Changes in fat and glucose oxidation upon $\beta$-adrenergic stimulation. Values (means $\pm \mathrm{SE}$ ) are areas under the curve of fat $(A)$ or glucose oxidation $(B)$ vs. time minus baseline $(\mathrm{mg} / \mathrm{min})$. Solid bar, DOB; gray bar, SAL; hatched bar, SAL+ACI. $* P<0.05$ vs. baseline; ${ }^{\#} P<0.05$ vs. SAL and SAL+ACI.

directly fueled by skeletal muscle. To this purpose, we examined the effect of $\beta_{2}$-adrenergic stimulation on energy expenditure with and without acipimox to suppress lipolysis. Acipimox indeed effectively suppressed lipolysis but did not affect the $\beta_{2}$-adrenergic receptormediated increase in energy expenditure. Thus the $\beta_{2}$-adrenergic-induced increase in energy expenditure is directly fueled by skeletal muscle energy sources and is not mediated by increased plasma FFA levels.
The increase in energy expenditure upon $\beta_{1}$-adrenergic receptor stimulation has been shown to be covered by an increased fat oxidation, and, again, this increase was reduced when lipolysis was inhibited during $\beta_{1}$-adrenergic stimulation with dobutamine (18). Also in the present study, dobutamine $\left(\beta_{1}\right)$ as well as salbutamol $\left(\beta_{2}\right)$ administration significantly increased fat oxidation compared with basal levels. However, the increase in fat oxidation was $\sim 2.6$-fold higher upon $\beta_{1}$-adrenergic stimulation by dobutamine than upon $\beta_{2}$-adrenergic stimulation by salbutamol, whereas the rise in energy expenditure and plasma FFAs was comparable between the two conditions, indicating that part of the increase in energy expenditure upon $\beta_{2^{-}}$ adrenergic stimulation was due to increased glucose oxidation. Schiffelers et al. (19) also studied the increase in fat oxidation after selective stimulation of the $\beta_{1}$-adrenergic receptor by dobutamine as well as after selective $\beta_{2}$-adrenergic receptor stimulation by salbutamol. In contradiction to our results, this study revealed that when energy expenditure was equally increased with certain concentrations of dobutamine and salbutamol, the relative contribution of fat oxidation to total energy expenditure was not different between $\beta_{1-}$ and $\beta_{2}$-adrenergic stimulation (19). However, in this study by Schiffelers et al., subjects received consecutive infusions of increasing concentrations of dobutamine and salbutamol, each dose for $30 \mathrm{~min}$, whereas in the present study, a fixed concentration was administered continuously for $3 \mathrm{~h}$. In the present study, administration of acipimox, to block lipolysis, completely abolished the $\beta_{2}$-induced increase in fat oxidation without affecting energy expenditure, again indicating that $\beta_{2}$-adrenergic stimulation directly influences glucose oxidation. This suggestion is underscored by the observation that the increase in fat oxidation was less pronounced during $\beta_{2}$-adrenergic stimulation than during $\beta_{1}$-adrenergic stimulation despite a similar increase in plasma FFAs and thermogenesis. Moreover, when plasma FFAs were reduced by inhibiting lipolysis with acipimox during $\beta_{2}$-adrenergic stimulation, glucose oxidation significantly increased by $\sim 27 \%$, completely covering the increase in energy expenditure. Taken together, these data indicate that, next to a small increase in fat oxidation driven by increased lipolysis, $\beta_{2}$-adrenergic stimulation also directly increases glucose oxidation. Previous studies have shown that nonselective blockade of all $\beta$-adrenergic receptors impeded enhancement of exercise-induced glycogenolysis in human skeletal muscle (4, 15). Chruscinski et al. (3) selectively disrupted the $\beta_{2^{-}}$ adrenergic receptor gene in mice and observed a lower RER during exercise in the knockout mice, suggesting that these mice may use a greater ratio of fat to carbohydrate than wild-type mice. Because during exercise glycogen provides a major part of the energy required, this observation is consistent with a role for the $\beta_{2^{-}}$ adrenergic receptor in the mobilization of glycogen (3). Specific $\beta_{1}$-adrenergic effects on glycogenolysis in skeletal muscle are unknown but seem unlikely, since skeletal muscle lacks $\beta_{1}$-adrenergic receptors (12). 
Fig. 5. Plasma free fatty acids (FFA) during $\beta$-adrenergic stimulation. Values are means $\pm \mathrm{SE}$.

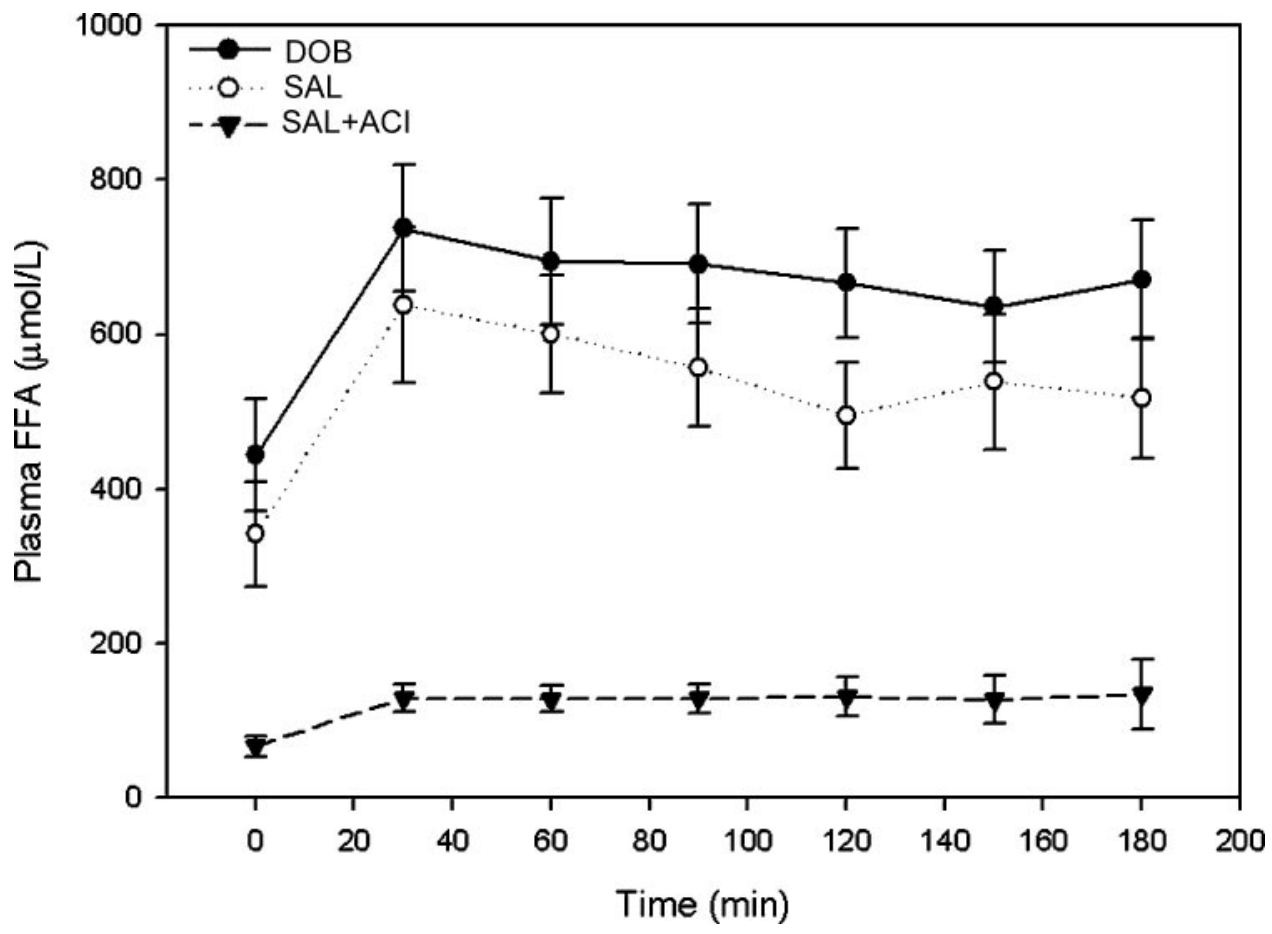

Independent of the substrate being oxidized, the mechanism for the increased thermogenesis in skeletal muscle upon $\beta$-adrenergic stimulation is unknown. Because UCP3 is capable of uncoupling $(5,7)$ and is

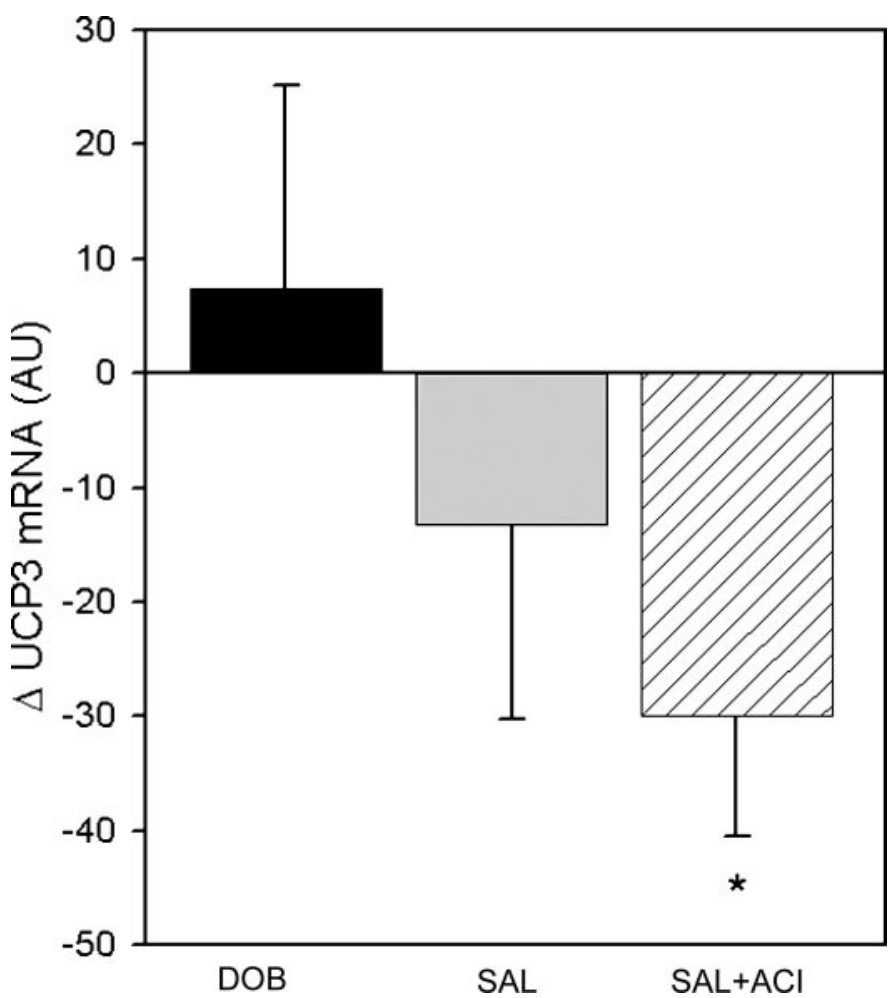

Fig. 6. Changes in uncoupling protein 3 (UCP3) mRNA levels after $\beta$-adrenergic stimulation. Values (means $\pm \mathrm{SE}$ ) are postexperimental UCP3 mRNA levels minus preexperimental levels (arbitrary units). ${ }^{*} P<0.05$ vs. baseline. primarily localized in skeletal muscle $(1,28)$, this protein is a potential mediator in this process. In the present study, we examined whether UCP3 mRNA expression is under regulation of the sympathetic nervous system. We found that administration of dobutamine or salbutamol did not upregulate UCP3 mRNA expression. Therefore, a stimulatory effect of $\beta_{1^{-}}$or $\beta_{2}$-adrenergic activity on skeletal muscle UCP3 mRNA expression cannot be concluded from the present study. Even more, UCP3 mRNA levels were significantly decreased when acipimox was coadministered with salbutamol, further indicating that $\beta$-adrenergic stimulation in humans does not upregulate UCP3 expression. However, low FFA levels seem to be responsible for the observed downregulation of UCP3 mRNA upon simultaneous administration of salbutamol and acipimox, further providing evidence for an important role of FFA in the regulation of UCP3. It has already been shown that high levels of plasma FFAs are able to upregulate skeletal muscle UCP3 $(11,17,29)$. Khalfallah et al. (11) increased plasma FFA concentrations in humans up to a final concentration of $989 \mu \mathrm{mol} / \mathrm{l}$ during triglyceride infusion and found a significant increase in UCP3 mRNA. Furthermore, we showed that acute exercise, a condition of increased energy expenditure, fat oxidation, and plasma FFA levels, upregulated skeletal muscle UCP3 mRNA (21). In addition, glucose ingestion, during and after exercise, abolished the commonly observed increase in plasma FFA levels and/or fatty acid oxidation and prevented the upregulation of UCP3 after acute exercise, indicating that the observed increase in UCP3 mRNA levels appeared to be an effect of elevated plasma FFA levels and/or increased fatty acid oxidation rather than an effect of increased energy expenditure (21). The lack of increase 
in UCP3 mRNA levels upon $\beta_{1^{-}}$and $\beta_{2}$-adrenergic stimulation in the current study, despite increased levels of plasma FFAs, might be explained by the fact that plasma FFA levels reached $50 \%$ of the values obtained by Khalfallah et al. (11) and our own laboratory (21). The present study is the first to show a significant downregulation of skeletal muscle UCP3 mRNA levels upon low plasma FFA concentrations in humans despite an increase in energy expenditure. This finding further favors a role for fatty acids in the regulation of UCP3 mRNA expression and suggests that the physiological function of UCP3 is more likely related to fatty acid metabolism than to the regulation of energy expenditure. From the present study, however, we cannot exclude the possibility that UCP3 protein content or UCP3 activity is altered upon $\beta$-adrenergic stimulation.

We recently suggested that UCP3 might act as a mitochondrial fatty acid anion exporter to prevent accumulation of nonmetabolizable and potentially toxic fatty acid anions inside the mitochondrial matrix (23), and the acipimox-induced downregulation of UCP3 is compatible with this hypothesis.

In conclusion, $3 \mathrm{~h}$ of infusion of both dobutamine $\left(\beta_{1}\right)$ and salbutamol $\left(\beta_{2}\right)$ increased energy expenditure, fat oxidation, and plasma FFA levels. In contrast to $\beta_{1^{-}}$ adrenergic stimulation, $\beta_{2}$-adrenergic stimulation increased energy expenditure independently of plasma FFA levels. Furthermore, $\beta_{2}$-adrenergic activity stimulated glucose oxidation, most likely due to increased glycogenolysis.

No evidence was found for a regulatory role for $\beta_{1}$ - or $\beta_{2}$-adrenergic activity on skeletal muscle UCP3 expression in this study, since neither salbutamol nor dobutamine affected UCP3 expression. However, significant downregulation of skeletal muscle UCP3 mRNA levels was observed upon low plasma FFA concentrations in humans, despite an increase in energy expenditure. Therefore, changes in UCP3 mRNA expression seem to be related to fatty acid metabolism rather than to energy metabolism. However, future studies are needed to reveal whether mitochondrial uncoupling, for example by increasing UCP3 activity, is involved in $\beta$-adrenergic-induced adaptive thermogenesis.

\section{DISCLOSURES}

P. Schrauwen and J. Hoeks were supported by grants from the Netherlands Organization for Scientific Research (NWO).

\section{REFERENCES}

1. Boss O, Samec S, Paoloni-Giacobino A, Rossier C, Dulloo A, Seydoux J, Muzzin P, and Giacobino JP. Uncoupling protein-3: a new member of the mitochondrial carrier family with tissue-specific expression. FEBS Lett 408: 39-42, 1997.

2. Cao W, Medvedev AV, Daniel KW, and Collins S. betaAdrenergic activation of p38 MAP kinase in adipocytes: cAMP induction of the uncoupling protein 1 (UCP1) gene requires p38 MAP kinase. J Biol Chem 276: 27077-27082, 2001.

3. Chruscinski AJ, Rohrer DK, Schauble E, Desai KH, Bernstein D, and Kobilka BK. Targeted disruption of the beta2 adrenergic receptor gene. J Biol Chem 274: 16694-16700, 1999.
4. Cleroux $\mathbf{J}$ and Leenen FH. Effects of beta-blockade on muscle metabolism during prolonged exercise. A short review. Am J Hypertens 1: 290S-294S, 1988.

5. Fleury C, Neverova M, Collins S, Raimbault S, Champigny O, Levi-Meyrueis C, Bouillaud F, Seldin MF, Surwit RS, Ricquier D, and Warden CH. Uncoupling protein-2: a novel gene linked to obesity and hyperinsulinemia. Nat Genet 15: 269-272, 1997.

6. Gomez-Ambrosi J, Fruhbeck G, and Martinez JA. Leptin, but not a beta 3-adrenergic agonist, upregulates muscle uncoupling protein-3 messenger RNA expression: short-term thermogenic interactions. Cell Mol Life Sci 55: 992-997, 1999.

7. Gong DW, He Y, Karas M, and Reitman M. Uncoupling protein-3 is a mediator of thermogenesis regulated by thyroid hormone, beta3-adrenergic agonists, and leptin. J Biol Chem 272: 24129-24132, 1997.

8. Heaton GM, Wagenvoord RJ, Kemp A Jr, and Nicholls DG. Brown-adipose-tissue mitochondria: photoaffinity labelling of the regulatory site of energy dissipation. Eur J Biochem 82: 515-521, 1978.

9. Himms-Hagen J. Brown adipose tissue thermogenesis and obesity. Prog Lipid Res 28: 67-115, 1989.

10. Himms-Hagen J. Brown adipose tissue thermogenesis: interdisciplinary studies. FASEB J 4: 2890-2898, 1990.

11. Khalfallah Y, Fages S, Laville $M$, Langin $D$, and Vidal $H$. Regulation of uncoupling protein-2 and uncoupling protein-3 mRNA expression during lipid infusion in human skeletal muscle and subcutaneous adipose tissue. Diabetes 49: 25-31, 2000.

12. Liggett SB, Shah SD, and Cryer PE. Characterization of $\beta$-adrenergic receptors of human skeletal muscle obtained by needle biopsy. Am J Physiol Endocrinol Metab 254: E795-E798, 1988.

13. Nagase I, Yoshida T, and Saito M. Up-regulation of uncoupling proteins by beta-adrenergic stimulation in L6 myotubes. FEBS Lett 494: 175-180, 2001.

14. Nakamura Y, Nagase I, Asano A, Sasaki N, Yoshida T, Umekawa T, Sakane N, and Saito M. Beta 3-adrenergic agonist up-regulates uncoupling proteins 2 and 3 in skeletal muscle of the mouse. J Vet Med Sci 63: 309-314, 2001.

15. Opie LH. Effect of beta-adrenergic blockade on biochemical and metabolic response to exercise. Am J Cardiol 55: 95D-100D, 1985.

16. Peronnet $\mathbf{F}$ and Massicotte $\mathbf{D}$. Table of nonprotein respiratory quotient: an update. Can J Sport Sci 16: 23-29, 1991.

17. Samec S, Seydoux J, and Dulloo AG. Interorgan signaling between adipose tissue metabolism and skeletal muscle uncoupling protein homologs: is there a role for circulating free fatty acids? Diabetes 47: 1693-1698, 1998.

18. Schiffelers SL, Brouwer EM, Saris WH, and van Baak MA. Inhibition of lipolysis reduces beta1-adrenoceptor-mediated thermogenesis in man. Metabolism 47: 1462-1467, 1998.

19. Schiffelers SL, Saris WH, Boomsma F, and van Baak MA. beta(1)- and beta(2)-Adrenoceptor-mediated thermogenesis and lipid utilization in obese and lean men. J Clin Endocrinol Metab 86: 2191-2199, 2001.

20. Schiffelers SL, van Harmelen VJ, de Grauw HA, Saris WH, and van Baak MA. Dobutamine as selective $\beta_{1}$-adrenoceptor agonist in in vivo studies on human thermogenesis and lipid utilization. J Appl Physiol 87: 977-981, 1999.

21. Schrauwen P, Hesselink MK, Vaartjes I, Kornips E, Saris WH, Giacobino JP, and Russell A. Effect of acute exercise on uncoupling protein 3 is a fat metabolism-mediated effect. Am $J$ Physiol Endocrinol Metab 282: E11-E17, 2002.

22. Schrauwen P, Hinderling V, Hesselink MK, Schaart G, Kornips E, Saris WH, Westerterp-Plantenga M, and Langhans W. Etomoxir-induced increase in UCP3 supports a role of uncoupling protein 3 as a mitochondrial fatty acid anion exporter. FASEB $J$ 16: 1688-1690, 2002.

23. Schrauwen $\mathbf{P}$, Saris WH, and Hesselink MK. An alternative function for human uncoupling protein 3: protection of mitochondria against accumulation of nonesterified fatty acids inside the mitochondrial matrix. FASEB J 15: 2497-2502, 2001.

24. Schrauwen P, Xia J, Bogardus C, Pratley RE, and Ravussin E. Skeletal muscle uncoupling protein 3 expression is a 
determinant of energy expenditure in Pima Indians. Diabetes 48: 146-149, 1999.

25. Simonsen L, Bülow J, Madsen J, and Christensen NJ. Thermogenic response to epinephrine in the forearm and abdominal subcutaneous adipose tissue. Am J Physiol Endocrinol Metab 263: E850-E855, 1992.

26. Simonsen L, Stallknecht B, and Bülow J. Contribution of skeletal muscle and adipose tissue to adrenaline-induced thermogenesis in man. Int J Obes Relat Metab Disord 17, Suppl 3: S47-S51, S68, 1993.

27. Siri W. The gross composition of the body. Adv Biol Med Physiol 4: 239-280, 1956.
28. Vidal-Puig A, Solanes G, Grujic D, Flier JS, and Lowell BB. UCP3: an uncoupling protein homologue expressed preferentially and abundantly in skeletal muscle and brown adipose tissue. Biochem Biophys Res Commun 235: 79-82, 1997.

29. Weigle DS, Selfridge LE, Schwartz MW, Seeley RJ, Cummings DE, Havel PJ, Kuijper JL, and BeltrandelRio $H$. Elevated free fatty acids induce uncoupling protein 3 expression in muscle: a potential explanation for the effect of fasting. Diabetes 47: 298-302, 1998.

30. Weir J. New methods for calculating metabolic rate with special reference to protein metabolism. J Physiol 109: 1-9, 1949.

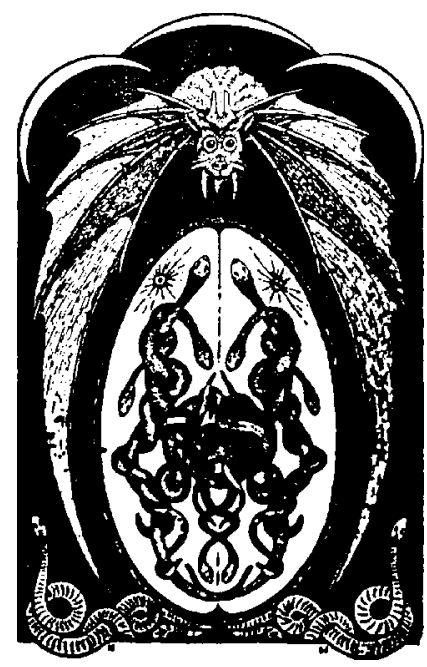

